\title{
Microflora of degraded desert-sandy soils in the case of Uzbekistan
}

\author{
Normamat Namozov ${ }^{1, *}$, Mirzabek Tursinbaev ${ }^{1}$, Iskandar Yuldoshev ${ }^{1}$, and Sakhibabonu \\ Yuldasheva $^{1}$ \\ ${ }^{1}$ Tashkent State Agrarian University, 100140, Tashkent province, Uzbekistan
}

\begin{abstract}
This article presents the results of a study conducted by desertsandy soils. In the studied desert-sandy soils rapid development of the studied microorganisms was observed mainly in the spring. Mushrooms, ammonificators and oligonitrophilic are sensitive in terms of optimal soil moisture, therefore increasing the number of them observed in the wet periods of the year. Actinomycetes are easier to tolerate unfavorable environmental conditions than other groups of microorganisms, therefore, their seasonal dynamics were insignificant.
\end{abstract}

\section{Introduction}

Soil is the main means of production for agriculture and is inextricably linked with the productivity, quality and productivity of agricultural crops $[1,2]$. In turn, fertility depends on all the properties of the soil, including the amount of nutrients and humus. Desert and semi-desert (arid) livestock have great potential in solving the problem of providing the population with livestock products. In addition, astrakhan leather is an export product, which increases the economic efficiency of the industry. Desert livestock are fed on plants in natural desert pastures throughout the year $[3,6]$.

Natural desert plants are recognized as the cheapest food source despite their low productivity. Effective use of desert pastures in the national economy should be based on a system of scientifically based agro-technical support [3,4]. Despite the fact that a lot of data on the dynamics of changes in the amount of microorganisms in the soil during the year has been collected, this problem is one of the absolutely unresolved problems. This is probably why there are some researchers who believe that the seasons do not significantly affect the change in the number of microorganisms. However, it is unanimously acknowledged by most researchers that it is not the seasons themselves, but all the events that take place in them that directly affect soil microorganisms $[5,7]$.

As bacteria multiply and multiply rapidly, a harmful substance called periodin accumulates in the soil, which drastically reduces the amount of bacteria [8]. By examining the activity of some enzymes in the southwestern Kyzylkum sandy-brown soils, the effects of higher plants on the growth and development of microorganisms were determined [912].

\footnotetext{
*Corresponding author: n.ch.namozov@yandex.com
} 
It has been noted that the biogenicity of brown sandy soils is very low and that nitrification processes are not visible or very low in these soils. The strong growth of bacteria and fungi in the spring in the soils of Kyrgyzstan has also been identified by the author. Their activity has been shown to decline during the summer and fall months. It was also noted that actinomycetes develop strongly during the summer months [6].

In sandy soils, it was found that the main group of microorganisms present in them, namely putrefactive bacteria, nitrifiers and nitrogen-fixing bacteria, were examined. In soils with heavy mechanical composition and clayey soils, the total number of microorganisms is very low, some physiological groups, for example: nitrifiers, nitrogen bacteria and actinomycetes are not found in this soil. In sandy soils, the overall group composition of microorganisms was found to be very low, but the growth and development of putrefactive bacteria was shown. As a result, it was found that the level of salinity of the soil affects the viability of microorganisms [4].

In our study, the dynamics of the development of groups of microorganisms in desert sandy soils was studied analytically on the basis of soil samples in spring, summer and autumn.

\section{Materials and methods}

There are different views on the properties of the microflora in soils located in different geographical directions. Structural and functional diversity in bacterial specificity geographical differences are less expressed in different types of soils, relative to the change in profile. In the distribution of microorganisms, the geographical factor is manifested by environmental factors of the soil, including: moisture, type of soil solution, acidity, temperature and salinity [5].

Due to the nitrogen-fixing activity of bacteria, up to $30-50 \mathrm{~kg}$ of accumulated nitrogen is accumulated annually in gray soils and up to $100 \mathrm{~kg}$ in tropical soils [2].

To understand the role of microorganisms in soil structure, it is important to know the description of different types and quantities of microorganisms. It is necessary to know the reserves of living microorganisms in different soil types and layers [9, 10]. Therefore, we divided the soil layer of our experimental area into several layer, considering the active root zone ranging from 0 to $80 \mathrm{~cm}$.

\section{Results and discussion}

Studies have shown that according to the results obtained in February, the amount of bacteria (MPA) in the $0-8 \mathrm{~cm}$ layer of the 6 th section was 110,000 cells per $1 \mathrm{~g}$ of soil. The lowest amount of bacteria was found in the layer at a depth of $21-41 \mathrm{~cm}$, which are 112 thousand cells per $1 \mathrm{~g}$ of soil. In the 7th section, it reaches 132,000 to 188,000 cells.

According to data obtained in April, bacteria make up 165 million cells at a depth of 0-8 $\mathrm{cm}$ in section 9, and 152-209 thousand cells at a depth of $0-8 \mathrm{~cm}$ in sections 10 and 11 . Depending on the amount of humus and nutrients, a sharp decrease in the number of bacteria is observed as they move to the lower layers (28-88 thousand cells in $1 \mathrm{~g}$ of soil). It can be seen that the highest amount of bacteria occurs in April (Table 1).

During our study, an increase in fungi was observed in April compared to February. At a depth of $0-8 \mathrm{~cm}$ layer of the 6th section, 14,000 cells go to the lower layers, and at a depth of $0-6 \mathrm{~cm}$ layer of the 10th section, 32,000 cells form 2-5,000 cells. By May, we can observe a slight decrease in the amount of fungi. At a depth of $0-8 \mathrm{~cm}$ in the 14 th section, 10,000 pieces go to the lower layers at a depth of $0-10 \mathrm{~cm}$ in the 13 th section, forming $2-$ 
7,000 cells. As can be seen from the above, the amount of fungi can be seen in the spring in desert-steppe soils (Table 1).

The amount of actinomycetes studied is not high. They are higher in April than in February. The table shows that there is no significant difference in the amount of actinomycetes in these soils. However, an increase in the amount of microorganisms of this group (15-28 thousand cells in $1 \mathrm{~g}$ of soil) is observed at the depth of 8-21 and $21-41 \mathrm{~cm}$ layers of section 6 (Table 1).

By May, it was observed that the amount of actinomycetes increased slightly to 6,000 cells at a depth of $0-12 \mathrm{~cm}$ in the 12th incision, reaching the lower layer (10-15 thousand cells). We can see that the 13 th section has decreased to 27,000 at a depth of $0-10 \mathrm{~cm}$, and the 15 th section has decreased to a depth of 46,000 at a depth of $0-7 \mathrm{~cm}$.

Table 1. Seasonal variation of the number of microorganisms in the soils of the experimental area (thousands per $1 \mathrm{~g}$ of soil)

\begin{tabular}{|c|c|c|c|c|c|}
\hline Layer numbers & $\begin{array}{l}\text { Depth of } \\
\text { layer, cm }\end{array}$ & Ammonifiers & $\begin{array}{c}\text { Oligonitrop } \\
\text { hils }\end{array}$ & $\begin{array}{c}\text { Actinom } \\
\text { ycetes }\end{array}$ & Fungi \\
\hline \multicolumn{6}{|c|}{ February 10, 2019 } \\
\hline \multirow{3}{*}{6} & $0-8$ & 110 & 54 & 8 & 14 \\
\hline & $8-21$ & 156 & 96 & 15 & 4 \\
\hline & $21-41$ & 112 & 56 & 28 & 7 \\
\hline \multirow{3}{*}{7} & $0-11$ & 188 & 94 & 37 & 7 \\
\hline & $11-39$ & 150 & 55 & 13 & 8 \\
\hline & $39-61$ & 132 & 25 & 9 & 2 \\
\hline \multicolumn{6}{|c|}{ April 24, 2019} \\
\hline \multirow{4}{*}{9} & $0-8$ & 165 & 72 & 36 & 24 \\
\hline & $8-25$ & 160 & 55 & 22 & 12 \\
\hline & $25-54$ & 88 & 34 & 12 & 5 \\
\hline & $54-80$ & 32 & 6 & 8 & 1.8 \\
\hline \multirow{3}{*}{10} & $0-6$ & 209 & 92 & 56 & 32 \\
\hline & $6-30$ & 156 & 44 & 36 & 15 \\
\hline & $30-60$ & 28 & 19 & 12 & 5 \\
\hline \multirow{3}{*}{11} & $0-9$ & 152 & 48 & 28 & 17 \\
\hline & $9-28$ & 100 & 32 & 22 & 10 \\
\hline & $28-60$ & 67 & 21 & 18 & 3.9 \\
\hline
\end{tabular}

The amount of oligonitrophils was higher than that of fungi and actinomycetes in the soils of the study area. In the soils in February, in the 6th section, there were 54,000 in the upper layers and 56,000 in the lower layers. In Section 7, there are 94,000 at a depth of 0 $11 \mathrm{~cm}$ and 25,000 at a depth of 39-61 cm. In April, 92,000 pieces at a depth of 0-6 cm in the 10th section and 72,000 pieces at a depth of $0-8 \mathrm{~cm}$ in the 9 th section. Going to the bottom layer, the indicators go down. The amount of oligonitrophils was almost the same in February and April (Table 1).

According to data obtained in May, bacteria make up 100 million cells at a depth of 0 $12 \mathrm{~cm}$ in section 12,101 million at a depth of $0-10 \mathrm{~cm}$ in section 13 , and 100-109 thousand cells at a depth of $0-8 \mathrm{~cm}$ in sections 14.15 and 16. Depending on the amount of humus and nutrients, a sharp decrease in the number of bacteria is observed as they move to the lower layers (28-96 thousand cells in $1 \mathrm{~g}$ of soil). It can be seen that the maximum number of bacteria decreased in May compared to April (Table 2). 
Table 2. Seasonal variation of the number of microorganisms in the soils of the experimental area (thousands per $1 \mathrm{~g}$ of soil)

\begin{tabular}{|c|c|c|c|c|c|}
\hline $\begin{array}{c}\text { Layer } \\
\text { numbers }\end{array}$ & $\begin{array}{c}\text { Depth of } \\
\text { layer, cm }\end{array}$ & Ammonifiers & $\begin{array}{c}\text { Oligonitrop } \\
\text { hils }\end{array}$ & $\begin{array}{c}\text { Actinom } \\
\text { ycetes }\end{array}$ & Fungi \\
\hline \multicolumn{6}{|c|}{ May 18, 2019 } \\
\hline \multirow{3}{*}{12} & $0-12$ & 100 & 44 & 6 & 10 \\
\cline { 2 - 6 } & $12-33$ & 116 & 56 & 10 & 4 \\
\cline { 2 - 6 } & $33-65$ & 96 & 36 & 15 & 7 \\
\hline \multirow{3}{*}{13} & $0-10$ & 101 & 84 & 27 & 7 \\
\cline { 2 - 6 } & $10-35$ & 98 & 35 & 9 & 8 \\
\cline { 2 - 6 } & $35-67$ & 86 & 15 & 9 & 2 \\
\hline \multirow{3}{*}{14} & $0-8$ & 105 & 52 & 26 & 14 \\
\cline { 2 - 6 } & $8-24$ & 96 & 35 & 12 & 9 \\
\cline { 2 - 6 } & $24-49$ & 80 & 24 & 6 & 5 \\
\hline \multirow{3}{*}{15} & $0-7$ & 109 & 72 & 46 & 12 \\
\cline { 2 - 6 } & $7-22$ & 78 & 44 & 16 & 7 \\
\cline { 2 - 6 } & $22-45$ & 28 & 19 & 12 & 5 \\
\hline \multirow{3}{*}{16} & $0-7$ & 100 & 38 & 18 & 10 \\
\cline { 2 - 6 } & $7-27$ & 80 & 22 & 12 & 8 \\
\cline { 2 - 6 } & $27-49$ & 47 & 11 & 9 & 3.9 \\
\hline
\end{tabular}

According to the table above, in May 2019, the number of oligonitrophils will be 44,000 in the upper layers of the 12th incision, 52,000 in the 14th incision, and 38,000 in the 16th incision. At the lower layers, a decrease in these values was observed. If the data obtained are analyzed, the time of growth and development of microorganisms in these soils was higher in April than in February.

\section{Conclusion}

The dynamics of seasonal change of a number of groups of microorganisms studied is related to the hydrothermal regime of soil types and the physiological properties of microorganisms. In desert sandy soils, the highest development of all microorganism groups is observed, mainly in the spring period.

Fungi, ammonifiers, and oligonitrophils are demanding to optimal soil moisture conditions, and therefore their highest amounts are observed during the wet periods of the year. Actinomycetes are also able to develop in severe soil-climatic conditions due to their physiological properties compared to other groups of microorganisms, and it was found that the dynamics of their seasonal change is insignificant.

\section{References}

1. M.U. Abdujalolova, In: Materials of the jubilee conference of microbiology, algology and mycology, dedicated to the 50th anniversary of the Uzbek SSR and the Communist Party of Uzbekistan, 2, 37-40 (1984)

2. E.G. Vukhrer, Microflora of soils in the southern part of Russia, 1, 89-117 (1996)

3. E.G. Vukhrer, M.U. Abdujalolova, D.G. Makhmudova, E.M. Gaykhenberger, Ecology, Physiology, Variability of Microorganisms, 12(3), 200-213 (1996)

4. E.G. Vukhrer, K.T. Shamsieva, Soil Science, 3 94-100 (1998)

5. D.G. Zvyagintsev, Soil Microbiology and Biochemistry, 2, 141-147 (2010) 
6. D.G. Zvyagintsev, Soil Microbiology and Biochemistry, 8, 39-42 (2012)

7. E.I. Kvasnikov, Microbiology, 22, 265-281 (2016)

8. V. Kimberg, Soils of the Desert Zone of Uzbekistan, 301 (2008)

9. S. K. Isaev, I. Begmatov, G. Goziev, S. Khasanov, In IOP Conference Series: Materials Science and Engineering, 883(1), 012080 (2020)

10. L.M. Polyanskaya, V.V. Geydebrekht, A.L. Stepanov, D.G. Zvyagintsev, Soil Science, 3, 322-328 (2005)

11. L.M. Polyanskaya, A.V. Golovchenko, D.G. Zvyagintsev, Microbial Biomass in Soils, 6, 846-848 (2005)

12. R. A. Kulmatov, S. A. Adilov, S. Khasanov, In IOP Conference Series: Earth and Environmental Science, 614(1), 012149 (2020) 